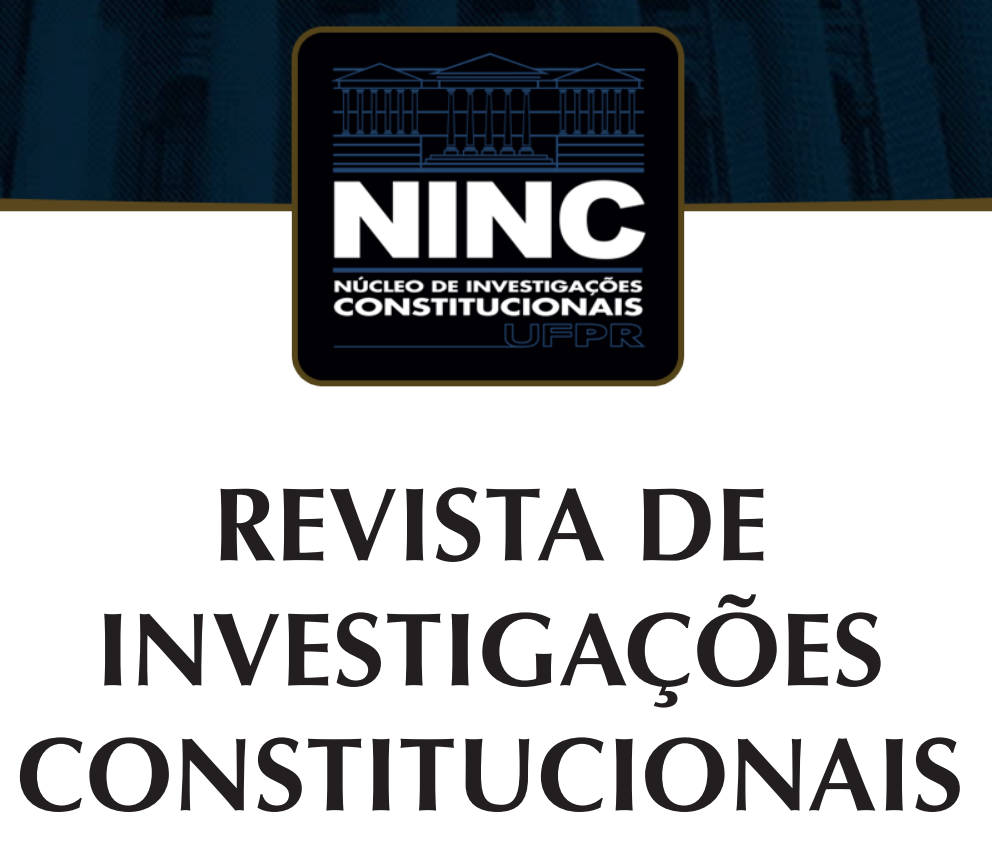

JOURNAL OF CONSTITUTIONAL RESEARCH

vol. 5 | n. 3 | setembro/dezembro 2018 | ISSN 2359-5639 | Periodicidade quadrimestral Curitiba | Núcleo de Investigações Constitucionais da UFPR | www.ninc.com.br 


\title{
Transforming the legislative: a pending task of Brazilian and Colombian constitutionalism*
}

\section{Transformando o legislativo: uma questão pendente dos constitucionalismos brasileiro e colombiano}

\author{
SANTIAGO GARCÍA-JARAMILLO** \\ Universidad de la Sabana (Colombia) \\ Pontificia Universidad Javeriana (Colombia) \\ garciajaramillosantiago@gmail.com \\ https://orcid.org/0000-0003-4969-7032
}

\section{CAMILO VALDIVIESO-LEÓN ${ }^{* * *}$}

Universidad de Los Andes (Colombia) valdiviesocamilo@gmail.com

https://orcid.org/0000-0003-3120-5829

Recebido/Received: 13.08 .2018 / August $13^{\text {th }}, 2018$ Aprovado/Approved: 03.09.2018 / September 3 ${ }^{\text {rd }}, 2018$

\section{Abstract}

The Constitutions of 1988 in Brazil and 1991 in Colombia have instantiated a complex process of transformative constitutionalism associated with the protection of rights, and the inclusion of minority groups. In spite of

\section{Resumo}

As Constituições do Brasil de 1988 e da Colômbia de 1991 deram início a um processo complexo de constitucionalismo transformativo associado à proteção de direitos e à inclusão de grupos minoritários. Apesar do papel

Como citar esse artigo/How to cite this article: GARCÍA-JARAMILLO, Santiago; VALDIVIESO-LEÓN, Camilo. Transforming the legislative: a pending task of Brazilian and Colombian constitutionalism. Revista de Investigações Constitucionais, Curitiba, vol. 5, n. 3, p. 43-58, set./dez. 2018. DOI: 10.5380/rinc.v5i3.60977.

"Some of the ideas discussed in this paper were reviewed and profited from the thoughtful comments, bibliography suggestions and discussions with Professors Andrei Marmor and Michael C. Dorf, during a research a visit at Cornell School of Law in spring 2018. The authors are really thankful for their patience, suggestions and criticism. The authors also like to thank professor Vicente Benitez-Rojas and Catalina Torres-Artunduaga for their comments and suggestions for this research, as well as to the law students Antonio Laborde-Baena, Daniel Currea-Moncada and Nicolas-Parra Gonzalez who helpfully assisted us in this research."

** Professor of Constitutional Theory at Universidad de La Sabana (Chía, Colombia), Constitutional Law at Pontificia Universidad Javeriana (Bogotá, Colombia), and visiting research scholar at Cornell University (Spring 2018). LL. B Pontificia Universidad Javeriana - Colombia - (2013) and specialization degree in Public Law at Universidad Externado de Colombia (2016). E-mail: garciajaramillosantiago@gmail.com.

*** Assistant Professor of International Investment Law at Universidad de Los Andes (Bogotá, Colombia). LL. B (2016) at Universidad de Los Andes (Colombia) and specialization degree (2018) in Public Management and Administrative Institutions at Universidad de Los Andes (Colombia). E-mail: valdiviesocamilo@gmail.com. 
the prominent role of the judiciary in these processes, it should be stated that these Constitutions recognized the importance of the legislative branch within the transformations they seek to achieve. The question that remains open is whether a strong intervention by the judiciary is instrumental to put the legislature back in shape and put it in tune with the transformation that both Constitutions seek to achieve. As this paper will show, despite the good decisions delivered when deciding particular cases, overall, transformative constitutionalism based on the prominent role of the Courts has not been that transformative in terms of reforming political institutions. In this sense, what this paper seeks to highlight is that, in order to develop an adequate theory on judicial review, it is crucial to truly identify the limitations of constitutionalism and what judicial review can and cannot do.

Keywords: transformative constitutionalism; representative democracy; judicial review; political institutions; comparative constitutionalism. proeminente do Judiciário nesses processos, deve-se afirmar que essas Constituições reconheceram a importância do Poder Legislativo dentro das transformações que buscam alcançar. A questão que permanece em aberto é se uma forte intervenção do Judiciário é fundamental para colocar o Congresso de volta em forma e colocá-lo em sintonia com a transformação que ambas as Constituições buscam alcançar. Como este artigo mostrará, apesar das boas decisões tomadas ao decidir casos particulares, em geral o constitucionalismo transformador baseado no papel proeminente dos Tribunais não tem sido tão transformador em termos de reforma das instituições políticas. Nesse sentido, o que este artigo procura destacar é que, para desenvolver uma teoria adequada sobre o controle judicial, é crucial identificar verdadeiramente as limitações do constitucionalismo e o que o controle judicial pode e não pode fazer.

Palavras-chave: constitucionalismo transformador; democracia representativa; controle judicial; instituições políticas; constitucionalismo comparado.

\section{CONTENTS}

1. Introduction; 2. Brazil 1988 and Colombia 1991: the establishment of value pluralism and the reinforcement of democracy; 3. Transformative constitutionalism and Political Institutions; 4. Conclusions and Final Remarks; 5. References.

\section{INTRODUCTION}

The enactment of the Constitution of the Federative Republic of Brazil, in 1988, marks a starting point for a time of constitutional transformations in Latin America. This Constitution, issued in an environment of distrust in the established public powers, is considered as the beginning of an era of democratization in the country, in which the Federal Supreme Court has had an increased role in its responsibility of "safeguarding the Constitution"1. Almost in parallel with this, and within the same perception of institutional distrust, in 1991 Colombia adopted its new Constitution based on democratic values and the protection of a wide range of fundamental rights (not only the classical liberal but also social and economic), establishing the Constitutional Court as an institution entrusted with safeguarding "the integrity and supremacy of the Constitution".

Although both countries share a long history of judicial review, after the 1988 and 1991 Constitutions, both the Federal Supreme Court in Brazil and the Constitutional Court in Colombia have had international recognition as agents of social change

\footnotetext{
${ }^{1}$ Constitution of the Federative Republic of Brazil. Art. 102.

${ }^{2}$ Political Constitution of Colombia. Art. 241.
} 
within systems in which democratic values are threatened due to somehow dysfunctional political institutions. Notwithstanding this, there have been several objections made to these Courts in the context of pluralist and rifted democratic societies, in particular, regarding their capabilities of transforming the political institutions, rather than making by themselves most of the decisions of principle and public policy.

This paper will analyze if the Constitutions of 1988 in Brazil and 1991 in Colombia were aimed at disenfranchising the political representative institutions. As it will be seen through a brief study of the formation of these Constitutions and their main institutional designs, instead of this, they aimed at reinforcing such institutions, opening them to "the people". In spite of the above, Courts have had a central role in developing these Constitutions, and despite the good decisions delivered when deciding particular cases, overall, transformative constitutionalism based on the prominent role of the Courts has not been that transformative in terms of reforming political institutions. In this sense, what this paper seeks to highlight is that, in order to develop an adequate theory on judicial review, it is crucial to truly identify the limitations of constitutionalism and what judicial review can and cannot do.

\section{BRAZIL 1988 AND COLOMBIA 1991: THE ESTABLISHMENT OF VALUE PLURALISM AND THE REINFORCEMENT OF DEMOCRACY}

In 1985, after more than two decades of military rule in Brazil, the newly elected civilian government adopted a constitutional amendment empowering the next Congress to serve as a constituent assembly ${ }^{3}$. Through a process of deliberation which involved the participation of 13 political parties that conformed an Assembly of 559 members, on October 5, 1988, and within the framework of a slow and gradual process of transition to democracy called abertura (opening) ${ }^{4}$, the new Constitution of the Federative Republic of Brazil was adopted. This constitutional process is highly valued by the idea of pluralism it implied, to the point that the 1988 Constitution is a highly complex document, which includes a long set of rights ${ }^{5}$, and judicial injuctions. Its content also has " a strong emphasis on human dignity (one of the constitution's fundamental principles), democratic rule, and a vast raft of fundamental rights, including a range of social and economic rights (although the text is silent as to whether they are justiciable)" ${ }^{\prime \prime}$. The

\footnotetext{
${ }^{3}$ Constitutional Amendment No. 26 of November 27, 1985.

${ }^{4}$ See, VIEIRA, Oscar Vilhena. The Descriptive Overview of the Brazilian Constitution and Supreme Court. In: VIEIRA, Oscar Vilhena (et. al.). Transformative Constitutionalism: comparing the apex courts of Brazil, India and South Africa, 2013. p. 75.

${ }^{5}$ Marmor has developed an argument stating that in divided societies which include value pluralism there is a strong tendency toward 'rights talk'. See, MARMOR, Andrei. On the limits of rights. In: MARMOR, Andrei. Law in the Age of Pluralism. Oxford Univeristy Press, 2007.

${ }^{6}$ DALY, Tom Gerald. The Alchemists: Questioning our Faith in Courts as Democracy-Builders. Cambridge: Cambridge University Press, 2017.
} 
1988 Constitution has been regarded as being designed to weaken the executive and to strengthen the legislature and judiciary?.

The judiciary, as established in the 1988 Constitution, "checks both the legislature and the executive through the power of judicial review"8. The Federal Supreme Court's review powers were enhanced by expanding access to an existing abstract review mechanism (the direct action of unconstitutionality) ${ }^{9}$. Notwithstanding the amplified role of the Court at the center of the constitutional order as being the "guardian of the Constitution $^{\prime 10}$, said powers were established with recognition to the other public powers (specially the legislative), and even exercised, at least during early stages of the new charter, with caution and restraint.

One example of this can be seen in the 1988 Constitution's measure regarding legislative omission, contained in paragraph 2, article 103 of the constitutional text ${ }^{11}$. This provision, rather than encouraging the Court to determine the content of the lacking measure or get into public policy making, is aimed at the issuance of a declaration of unconstitutionality and a notification to the competent power for the adoption of the necessary actions. The judiciary is called to raise a 'red flag' when action is needed, but not to take action by itself ${ }^{12}$. In exercising this power,

[u]nlike the Hungarian Constitutional Court's energetic and expansive use in the early 1990's of its power to address legislative omission (before it fell out of favor with the judges), the Brazilian Supreme Court took a relatively cautious approach to its new power to address legislative omission, keeping to simple declarations that legislation was required to give effect to a constitutional provision ${ }^{13}$.

\footnotetext{
${ }_{7}^{7}$ See, ROSENN, Keith. Separation of Powers in Brazil. Duquesne Law Review, Miami, v. 47, p. 839-870, 2009. ${ }^{8}$ ROSENN, Keith. Separation of Powers in Brazil. Duquesne Law Review, Miami, v. 47, p. 839-870, 2009.

${ }^{9}$ For a summary on judicial review in the Brazilian system, see: MALISKA, Marcos. The Brazilian Judicial Review. Education \& Science Without Borders, Curitiba, vol. 6, n. 12, p. 54-57, 2015. As the author exposes, "In the Brazilian constitutional system all judges have constitutional jurisdiction. In other words all judges have the power to declare a law unconstitutional. The declaration of unconstitutionality is made incidentally in the judicial case that is being analyzed. There is in Brazil the concentrated control of constitutionality too. In the concentrated control of constitutionality the Supreme Federal Court is the only competent organ of the judiciary to rule on the claim of unconstitutionality. These are called direct actions of the unconstitutionality in which the main claim (merit of action) is a declaration of unconstitutionality. In these lawsuits there is not proper case, only an abstract discussion if a law is not contrary to the constitution".

${ }^{10}$ Constitution of the Federative Republic of Brazil. Article 102.

${ }^{11}$ Constitution of the Federative Republic of Brazil. Article 103. "Paragraph 2. When unconstitutionality is declared on account of lack of a measure to render a constitutional provision effective, the competent Power shall be notified for the adoption of the necessary actions and, in the case of an administrative body, to do so within thirty days".

${ }^{12}$ A similar process, was proposed in Colombian in the 1910 constitutional assembly, although a model of 'strong' judicial review was finally enacted.

${ }^{13}$ DALY, Tom Gerald. The Alchemists: Questioning our Faith in Courts as Democracy-Builders. Cambridge: Cambridge University Press, 2017.
} 
In addition to this, it should be noted that the institutional design established in the 1988 Constitution gave great prominence to the legislative branch, which was entrusted with the power of regulating constitutional provisions through statutory lawmaking, thus recognizing the importance that Congress should have in the development of constitutional values ${ }^{14}$. In this sense, more than seeking to disenfranchise the political representative institutions, the Constitution aimed at confronting the previous hegemonic supremacy of the executive branch, in favor of a harmonious collaboration with the legislative branch which was in charge of regulating the content of the constitutional text, and with a Federal Supreme Court granted with renewed powers.

In the Colombian context, in 1991 a Constitutional Assembly, that enjoyed the support of the majority of society ${ }^{15}$, was regarded as a "consensual attempt to broaden democracy, as a means to confront a generalized state of political corruption and violence ${ }^{\prime 16}$. This Assembly became an icon of a peaceful transition, and the recognition of value pluralism that achieved an inclusive dialogue between different sectors of the Colombian society. Even guerrilla groups, indigenous and afro communities were given a seat at the Assembly. Furthermore, the M-19 -a former guerrilla group- won an important part of the Assembly seats ${ }^{17}$. The enacted constitutional text introduced a wide catalogue of rights ${ }^{18}$, and new and more inclusive judicial procedures for the enforcement and protection of fundamental rights like the acción popular, acción de grupo and acción de tutela were adopted.

The institutional design adopted by the 1991 Constitution was complex: the Constitutional Court was created as a'powerful court', but entrusted with an exhaustive list of functions such as judicial review of laws, judicial review on procedural grounds of constitutional amendments, and as a check on the executive branch during 'times of emergency' (among others). In addition to this, said Court was entrusted with the fundamental rights adjudication, when undertaking the review of the expedite protection of such rights via accion de tutel $a^{19}$, by other judges.

\footnotetext{
${ }^{14}$ See, Constitution of the Federative Republic of Brazil. Articles 44-75.

${ }^{15}$ For a comprehensive account of this process see, LEMAITRE RIPOLL, Julieta. EI Derecho Como Conjuro. Bogotá: Uniandes y Siglo del Hombre Editores, 2009.

${ }^{16}$ UPRIMNY YEPES, Rodrigo. Should Courts enforce Social Rights? The Experience of the Colombian Constitutional Court. In: COOMANS, Fons, (ed.). Justiciability of Economic and Social Rights: Experiences from Domestic Systems. Antwerpen-Oxford: Intersentia, 2006.

${ }^{17}$ In fact, it was the second political force at the Constitutional Assembly, just after the traditional liberal Party.

${ }^{18}$ Although the Constitutional text, in article 85 , specified that just some rights would have immediate application (mostly classical liberal-individual rights) while the others, should be subject to legislative development. While the Colombian Constitution does not include a clause like article 103.2 of the Brazilian Constitution, the Court has developed almost every right in the Constitution, even in absence of legislative action, this has been controversial even within the Court, as can be seen in the concurring opinion of decision T-175 of 2013.

${ }^{19}$ Article 86 of the 1991 Colombian Constitution defines the tutela by stating that: "Every individual may claim legal protection before the judge, at any time or place, through a preferential and summary proceeding, for himself/herself or by whoever acts in his/her name, the immediate protection of his/her fundamental
} 
However, one of the main aims of this Assembly was to rescue the legislative branch from the ostracism that it had under the 1886 Colombian Constitution, due to the excessive power given to the executive branch. In this sense, for instance, one of the delegates at the Constituent Assembly expressed that:

[t]he Legislative branch cannot transfer to the hands of another the power to make laws, due to the fact that it only has that power by delegation of the people (...) the legislative branch cannot transfer its power to another branch, it must be kept where the people bestowed it. In our country, the Executive branch through its famous extraordinary faculties expedites ninety percent of our statutes, such powers must disappear ${ }^{20}$.

Although both the Brazilian and Colombian Constitutions have instantiated a complex process of transformative constitutionalism associated with the protection of rights ${ }^{21}$, and the inclusion of minority groups, it should be stated that both Constitutions recognized the importance of the legislative branch within this process, on the one hand, and empowered the Courts in its limited functions as "guardians" of the Constitution, on the other. The question that remains open is whether a strong intervention by the judiciary is instrumental to put the legislature back in shape ${ }^{22}$ and put it in tune with the transformation that both Constitutions seek to achieve.

constitutional rights when the individual fears the latter may be jeopardized or threatened by the action or omission of any public authority (...)".

${ }^{20}$ See, 1991 Constituent Assembly Records, Delegate Jaime Arias López (1991). At. Volume 80, p. 3.

${ }^{21}$ It is a highly contested issue, whether such transformation should be undertaken by the Court itself or by political institutions. For instance, Ruth Gavison has developed a critical assessment toward strong judicial activism aimed at 'social transformation'. See, GAVISON, Ruth. The Role of Courts in Drifted Democracies. Israel Law Review, vol. 33, n. 2, p. 216-258. 1999.

${ }^{22}$ David Landau, has argued that the Colombian Court has tried to do this in some decisions, basically in the decision C-816 of 2004. See, LANDAU, David. A Dynamic Theory of Judicial Role. Boston College Law Review, Boston, vol. 55, n. 5, p. 1501-1562. 2014. Also, the Colombian Constitutional Court, in a recent decision (C-332 of 2017) stated that deliberation in Congress is fundamental to the 1991 Constitution, and thus struck down part of the special process for the implementation of the peace agreement signed between the Colombian government and FARC guerilla, which limited congressional deliberation. Although this decision may be regarded as a good decision in terms of proctecting deliberation, several objections can be raised to the theory used by the Court to reach such decision, for instance see the dissenting opinion by Justice Alejandro Linares-Cantillo.

For a general objection to this theory of unconstitutional constitutional amendments, see: BENITEZ, Vicente. Constitución Popular, No Judicial:una teoría democrática del controldeconstitucionalidad delas reformasala Constitución en Colombia. Bogotá, Legis, 2014 and GNECCO, Francisco; GARCIA, Santiago, La teoría de la sustitución: de la protección de la supremacía e integridad de la constitución, a la aniquilación de la titularidad del poder de reforma constitucional en el órgano legislative. Revista Universitas, vol. 65, No. 133, 2016. p. 59-103. 


\section{TRANSFORMATIVE CONSTITUTIONALISM AND POLITICAL INS- TITUTIONS}

Even though, both the Brazilian and the Colombian Constitutions aimed at strengthening the political process ${ }^{23}$ and the legislative branch, most of the constitutional law literature continues to portray legislators, in theoretical studies, as self-interested individuals seeking only to win reelection and maximize their private interests. Thus, they are shown as not to be trustworthy of "the people", and even more, as individuals who can not take the Constitution and the values and rights it includes seriously $^{24}$. Legislators are not only depicted as being vulnerable to the public opinion, as the result of being dependent on the electoral democratic process, but also Congress itself is shown as a dysfunctional institution worried only on bargaining on self-interest, but not in achieving the well-being of the citizens. Congress is shown as being unable to have discussions of principles, while the judiciary is a 'forum of principles ${ }^{25}$. Perhaps, in countries like Colombia and Brazil, it is hard to undertake an empirical defense of legislatures $^{26}$, but it is worth considering that their Constitutions were not aimed at disenfranchising Congress as a political-representative institution, but rather to transform it into a pluralist forum that can truly exemplify their citizens, as well as the plurality that lies at the base of the population, cultures, and moral-political thought.

Even if both the Brazilian Federal Supreme Court and the Colombian Constitutional Court play a central role in the constitutional arrangements of both Constitutions, it must be acknowledged that Congress has not disappeared from constitutional designs. Congress, in a Constitution like the Colombian and the Brazilian "is not a supreme institution", it is limited by it, "but this desirable limitation of the power of the legislature should not be taken to mean that is has lost its status as the best reflection within government of the source of political power- the people-"27. There is an urgent need in constructing a narrative of Congress as an institution that, in the light of pluralism and disagreement, can

\footnotetext{
${ }^{23}$ In a recent work on transformative constitutionalism, it has been argued how it is not circumscribed to the Global South, and also how the transformations it seeks to achieve are not limited to battles in Constitutional Courts. See, HAILBRONNER, Michaela. Transformative Constitutionalism: Not Only in the Global South. American Journal of Comparative Law, vol. 65, n. 3, p. 527-565, Nov. 2017.

${ }^{24}$ For a description on this assumption see: PARKER, Richard. "Here, the People Rule": A Constitutional Populist Manifesto. Boston: Harvard University Press, 1994.; WALDRON, Jeremy. Law and Disagreement. Oxford University Press, 1999.; GARRET, Elizabeth; VERMEULE, Adrian. Institutional Design of a Thayeran Congress. Duke Law Journal, vol. 50, n. 5, 2001.

${ }^{25}$ DWORKIN, Ronald. The forum of principle. New York University Law Journal, vol. 56, n. 469, 1981.

${ }^{26}$ This argument is circumscribed to these particular contexts, provided that authors like Jeremy Waldron have also undertaken empirical defense of legislatures. See: WALDRON, Jeremy. Law and Disagreement. Oxford University Press, 1999; BAUMAN, Richard; KAHANA, Tsvi. The least examined branch. Cambridge: Cambridge University Press, 2006; WALDRON, Jeremy, The Dignity of Legislation. Cambridge University Press, 1999.

${ }^{27}$ GAVISON, Ruth. Legislatures and the Phases and Components of Constitutionalism. In: BAUMAN, Richard; KAHANA, Tsvi (Eds.). The least examined branch. Cambridge: Cambridge University Press, 2006.
} 
truly respect the equality of all citizens by the democratic process of decision-making, by giving them the opportunity of having their interests equally considered ${ }^{28}$ and by the same token giving them the possibility to influence the decision stage. Thus, there is a need to recover the willingness of citizens to engage in a deliberative process with those who they disagree, in the political arena and not only through litigation ${ }^{29}$.

During the last decades, and due to the good particular results that judicial decisions have achieved ${ }^{30}$, there has been very few scholarly interest in examining legislatures, and thinking on how they can be improved, in order to implement the values that were entrenched in highly plural and democratic Constitutions like the Colombian and the Brazilian. However, building an aspirational idea of Congress can instantiate a healthy discussion on the legal and constitutional reforms that are needed to put this institution back in shape.

Such depiction of Congress should depart from the same idea of value pluralism entailed by these Constitutions. As a result of such pluralism, the Constitution includes abstract and open-ended clauses that are undeniably essentially contested concepts $^{31}$. As Marmor describes them, they are "general constitutional provisions containing abstract moral-political principles" which "might be seen as a kind of vague and general framework, setting the language in which moral-political concerns need to be phrased, but leaving the content of the relevant expressions free for us to shape as we deem right at any given time $e^{\prime 32}$. Such approach leads to the question of who should shape those general constitutional provisions.

In a pluralist society committed with some form of equal distribution of political power $^{33}$, the answer seems to be in favor of the people themselves or through their elected and accountable representatives, in a deliberative scenario, under the rules of some epistemic procedures where political equality is guaranteed by openness of deliberation, and voting as aggregation comes after a careful public debate ${ }^{34}$.

\footnotetext{
${ }^{28}$ See, CHRISTIANO, Thomas. The Authority of Democracy. The Journal of Political Philosophy, vol. 12, n. 3, 2004.; and MARMOR, Andrei. Authority, Equality and Democracy. In: MARMOR, Andrei. Law in the Age of Pluralism. Oxford University Press, 2007.

${ }^{29}$ For a comprehensive account of this, see: MORTON, F.L.; KNOPFF, RAINER. The Charter Revolution \& The Court Party. University Toronto Press, 2000.

${ }^{30}$ See, UPRIMNY YEPES, Rodrigo. Should Courts enforce Social Rights?: The Experience of the Colombian Constitutional Court. In: COOMANS, Fons, (ed.). Justiciability of Economic and Social Rights: Experiences from Domestic Systems. Antwerpen-Oxford: Intersentia, 2006.

${ }^{31}$ See, GALLIE, W.B. Esentially Contested Concepts. Proceedings of the Aristotelian Society, vol. 56, n. 167, 1955-1956. p. 167-198.

${ }^{32}$ MARMOR, Andrei. Meaning and Belief in Constitutional Interpretation. Fordham Law Review, vol. 82, n. 565, nov. 2013.

${ }^{33}$ See, MARMOR, Andrei. Law in the Age of Pluralism. Oxford University Press, 2007.

${ }^{34}$ ESTLUND, David (et. Al). The Place of Self-Interest and the Role of Power in Deliberative Democracy. The Journal of Political Philosophy, vol. 18, n. 1, 2010, p. 54-100.
} 
It far exceeds the aim of this paper to provide a comprehensive description of what reforms should be undertaken as to have a well-ordered legislative branch. But a sound institutional design of Congress must arise as a truly deliberative institution which not only hears but also values the voices of the minority groups, of regional interests, and of the laymen. It should be an institution with clear and easy to understand rules of deliberation that not only enhances debate and allows the intensity of preference to be duly channeled, but also respects equality at the decision stage. The electoral arrangements should be constructed to allow elections to be truly ruled by the principle of one-person one-vote, and not to be distorted through the flow of money to politics ${ }^{35}$. Congress should be committed to deliberation, as Vermeule and Garret explain,

deliberation exploits the collective character of legislatures in ways that can, in principle, improve Congress's constitutional performance. Among the concrete benefits of deliberation are its tendencies to encourage the revelation of private information, to expose extreme, polarized viewpoints to the moderating effect of diverse arguments, to legitimate outcomes by providing reasons to defeated parties, and to require the articulation of public-spirited justification for legislator's votes [...] In addition, deliberation makes congressional decision-making more accessible and transparent to the public, which increases accountability of the decision makers and may enhance the perceived legitimacy of the outcome ${ }^{36}$.

Also, a culture of accountability must be promoted among citizens, so that the self-interest of reelection can be connected to the broad interest of respect for the Constitution and people's rights.

As some authors have pointed out, discussions at legislative level with the involvement of citizens and their representatives might instantiate a culture of tolerance among citizens. Jeremy Waldron has stressed this argument by following the thoughts of the philosopher Bernard Williams and pointing out the difference between being able to say to a losing opponent, "Well, you lost" and saying to him, "You were wrong" or "You were proved wrong." The former saying, "Well you lost," is compatible with recognizing his position as honest and honorable; it's like saying, "Better luck next time."137. In his view, the first attitude, being associated with the democratic and majoritarian procedures,

\footnotetext{
${ }^{35}$ In the Brazilian context, Roberto Unger has called for an urgent reorganization of electoral politics, and the empowerment of the Civil Society. See, UNGER, Roberto Mangabeira. Democracy Realized: the progressive alternative. New York: Verso, 2001.

${ }^{36}$ GARRET, Elizabeth; VERMEULE, Adrian. Institutional Design of a Thayeran Congress. Duke Law Journal, Vol. 50, No. 5, 2001.

${ }^{37}$ This argument is taken from a lecture delivered by Jeremy Waldron, Forthcoming in Spanish: WALDRON, Jeremy. Control de Constitutionalidad y Legitimidad Política. Díkaion, Vol. 27, No. 1, 2018.
} 
and the last one being more common with 'moral victories' within the process of interpretation of abstract terms by courts, a process that might send a message that such decisions might be reached in a sort of timeless fashion, declaring a timeless moral truth, as it were; with the problem for civil tolerance, that such a message conveys to the losing party that it has got its profound moral principles wrong ${ }^{38}$. Although these arguments are not conclusive, they should give us some pause as for thinking on courts as the sole agents in the application of a transformative constitution, -usually ruling in highly divided societies, aiming at reconciliation and at a higher level of tolerance and civilityand should call for more attention to improve the shape of representative institutions like legislatures.

After these brief considerations on the role of Congress in the context of constitutionalism, it is important to ask whether the strong intervention of the Courts, by means of judicial review, that has been the consequence of both the Brazilian and Colombian 1988 and 1991 constitutions, respectively, can be helpful for shaping a'healthy legislature'. Sometimes it is assumed that a strong substantial intervention by Courts will improve the quality of legislative outcomes, provided that "if legislators know in advance that a piece of legislation they seek to enact is likely to be struck down as unconstitutional, they would refrain from trying to enact it".

However, as Garret and Vermeule explain, "that it is just not necessarily, or even typically, the case; scholars have long pointed out that legislators often go ahead with an act they expect to be struck down as unconstitutional because it gives them the populist political benefit vis-à-vis their constituents without actually bearing the responsibility for the unwanted consequences of the proposed legislation" ${ }^{\prime 39}$. In this sense, critics of judicial review doubt that substantive judicial intervention is good for putting back into shape a dysfunctional legislative institution. For instance, Tushnet has argued that since legislators act in the in the court's shadow, "we really cannot know how Congress would perform if the courts exited, if Congress does badly because the Courts are on the scene" ${ }^{\prime \prime 0}$.

On the other hand, Marmor also questions this possibility, based on the fact that unconstitutionality is not regarded as a sanction on the legislature, and therefore it does not deter Congress from proposing and enacting questionable measures, thus opening the doors for openly unconstitutional and populist proposals. At the end, following Marmor's observations, a strong intervention from the constitutional courts can promote the disenfranchisement of a culture of political accountability, based

\footnotetext{
${ }^{38}$ MARMOR, Andrei. Constitutional Interpretation. USC Law and Public Policy Research Paper, Los Angeles, vol. 4, n. 4, 2004.

${ }^{39}$ MARMOR, Andrei. Randomized Judicial Review. USC Law Legal Studies Paper, Los Angeles, vol. 15, n. 8, 2015.

${ }^{40}$ TUSHNET, Mark. Taking the Constitution Away from the Courts. Princeton University Press, 2000.
} 
on constitutional grounds ${ }^{41}$. Furthermore, even defenders of judicial review, as Waluchow, call the attention on the need to undertake reforms to improve the legislative branch, and not to solely rely on the decisions of courts, even if they might yield good decisions ${ }^{42}$.

Other accounts, which favor judicial review, but take a modest approach towards the changes it can achieve ${ }^{43}$, highlight that judicial intervention can be instrumental to strengthen the democratic decision making, and even fortify the representative institutions as the legislatures. Hart Ely, for example, argued that judicial review could be used as a guardianship on the existence conditions of laws ${ }^{44}$, and especially in the deliberative conditions that a representative democracy needs, like the inclusion of the minorities in the debates and decision-making on topics that certainly affect them ${ }^{45}$. In a case-based study of new democracies, including Brazil and Colombia, Daly has shown that this assertion is not conclusive, but that even said courts themselves cannot achieve all the changes needed for a well-shaped democracy there are some steps that these courts can help to take toward democratization ${ }^{46}$.

Therefore, the question on whether constitutional courts are good at promoting deliberation and democracy, is a contested matter, but a constitutional court can be regarded as an antidote to the pathologies of the democratic process ${ }^{47}$, and therefore, as having a limited role as to be in charge of reviewing the existence conditions of the laws, and undertaking a procedural review of the legislature, but not as a mere

\footnotetext{
${ }^{41}$ See, MARMOR, Andrei. Randomized Judicial Review. USC Law Legal Studies Paper, Los Angeles, vol. 15, $\mathrm{n}$. 8,2015 . This argument is also developed by BRADLEY THAYER, James. The Origin and Scope of the American Doctrine of Constitutional Law. Harvard Law Review, vol. 7, n. 3, Oct. 25, 1893.; GARRET, Elizabeth; VERMEULE, Adrian. Institutional Design of a Thayeran Congress, Duke Law Journal, Vol. 50, No. 5, 2001.

${ }^{42}$ WALUCHOW, Wilfrid. A Common Law Theory of Judicial Review: The living Tree. Cambridge Studies in Philosophy and Law. 2009.

${ }^{43}$ Some authors, like Richard Fallon Jr. have portrayed judicial review, as an additional check that might improve the protections of rights. However, this account of judicial review, does not deny the need of a strong legislature, as a forum where rights can also be defended and protected. See, FALLON, Richard. The Core Of An Uneasy Case For Judicial Review. Harvard Law Review, vol. 121, n. 7, May, 2008.

${ }^{44}$ ADLER, Matthew; DORF, Michael. C. Constitutional Existence Conditions and Judicial Review. Virginia Law Review, vol. 89, n. 6, 1105-1202, Oct. 2003.

${ }^{45}$ See, HART ELY, John. Democracy and Distrust. Harvard University Press, 1980.

${ }^{46}$ DALY, Tom Gerald. The Alchemists: Questioning our Faith in Courts as Democracy-Builders. Cambridge: Cambridge University Press, 2017.

${ }^{47}$ Some authors have argued that this antidote can be dangerous for pluralist and democratic societies, provided that judges may use their powers to favor some sort of status-quo, rather than to empower disenfranchised groups. The role of judges, briefly described here is modest, and restrained, and the interventions hereby proposed are more in the context of the "non-core" cases that Waldron exemplifies in The Core of the Case against Judicial Review. For this discussion see: MORTON, F.L.; KNOPFF, RAINER. The Charter Revolution \& The Court Party. University Toronto Press, 2000.; MANDEL, Michael, The Charter of Rights and the Legalization of Politics in Canada. Thompson Educational Publishers, 1994.; MANDEL, Michael. A Brief History of the New Constitutionalism, or "How We Changed Everything So that Everything Would Remain the Same. Israel Law Review. vol. 32, n. 2, 1998.
} 
review of formalism, but also as making sure that the rules of deliberation ${ }^{48}$, and the inclusion of the minorities and disenfranchised groups are met. Those are minimal conditions of a pluralist democracy, as the one aimed by both the Brazilian and Colombian Constitutions.

As a result, in Constitutions like the Brazilian and the Colombian, the role of judges should be aimed at the transformation of the legislative branch ${ }^{49}$, not as to disappear it or to disenfranchise it from the discussions on questions of principle, rights and public policy, but rather to promote the conditions of deliberation in the political branches, and to truly transform it into a pluralist, and politically accountable forum where the discussions needed in the context of the transformative constitutionalism can take place. It has been a long-contested issue whether courts can bring about social chan$\mathrm{ge}^{50}$, but even when the answer to this issue goes to the court's side, it is uncontested that legislatures are also needed in the process of achieving a true and lasting social change. First, because they are instrumental to open spaces where decisions are taken in the midst of a pluralist assembly, that reflects the differences and the diversity of societies, and that at the end are accountable to the citizens ${ }^{51}$. Legislatures in well shape, can promote deliberation not only at the elected representatives level, but also at the

\footnotetext{
${ }^{48} \mathrm{~A}$ similar argument, was put forward by Dorf and Sabel, who described that judicial review could serve democracy by giving fewer definitive answers to legal, social, and ultimately political questions while inquiring into more of the political actors' own deliberative capacities. Thus, they proposed judicial review to be exercised as a review of the admissibility of the reasons private and political actors themselves give for their decisions, and the respect they actually accord those reasons: a review, that is, of whether the protagonists have themselves been sufficiently attentive to the legal factors that constrain the framing of alternatives and the process of choosing among them. DORF, Michael C.; SABEL, Charles F. A Constitution of Democratic Experimentalism. Columbia Law Review. vol. 98, n. 2, Mar, 1998.

${ }^{49}$ This approach also demands restraint and humility from the Courts, provided that, as Daly (2017) states, a strong judicialization of politics "should not glibly be taken as a sign of a positive democratization trajectory, it can just as easily signal deep-rooted problems in a state's democratic development", it is preferable to have some deference toward the political process self-regulations, as Garret (2002) explains "judicial decisions that establish the structure of parties are problematic because courts constitutionalize the policy choices they make, even though those choices are not necessarily compelled by the Constitution". This deference is justified, for example, when the political powers show that they are capable of protecting dissent and minorities, as recently happened in Colombia with the enactment of a statute protecting political opposition, which was upheld by the Court in decision C-018 of 2018.

${ }^{50}$ See, RODRÍGUEZ GARAVITO, Cesar; RODRÍGUEZ FRANCO, Diana. Cortes y cambio social: cómo la Corte Constitucional transformó el desplazamiento forzado en Colombia. Colección Dejusticia, 2010.; BONILLA, Daniel (ed.). Constitucionalismo del Sur Global. Bogotá: Siglo del Hombre Editores. 2015. More critical views are pointed out in the following: GARGARELLA, Roberto. La Sala de Máquinas de la Constitución: dos siglos de constitucionalismo en América Latina (1810-2010). Buenos Aires: Katz Editores, 2015.; DALY, Tom Gerald. The Alchemists: Questioning our Faith in Courts as Democracy-Builders. Cambridge: Cambridge University Press, 2017.; ROSENBERG, Gerarld. The Hollow Hope. University of Chicago University Press, 2008.

${ }^{51}$ As Gavison, states Courts can help strengthen political institutions, if they "are there to strengthen accountability, but their functioning should not undermine the effectiveness of government. Furthermore, political, non-judicial forces should have a large role in strengthening the "accountability" side of government and legislatures". See, GAVISON, Ruth. The Role of Courts in Drifted Democracies. Israel Law Review, vol. 33, n. 2, p. 216-258. 1999.
} 
laymen level, thus promoting a democratic culture where the questions of principle and public policy are opened to all the persons affected by them and not only to elites of either politicians or jurists.

Latin-American scholars have pointed out how the constitutions regarded as transformative have not been so ambitious in reshaping the political institutions ${ }^{52}$. In spite of the rich catalogue of rights that they have included, and the positive role that they claim from the State as to make them available for all citizens, the organic structure of these constitutions remains similar to the one that the constitutionalism from the XIX century promoted. However, this process of transformation should also be taken to the organic level, and perhaps more efforts should be made to rescue the legislative branch, as a forum where the content of these rights, and social changes could be achieved, in light of an inclusive deliberation among equals ${ }^{53}$, where the representatives of the people are free to speak without unwanted interruptions or intimidations, by arguments justified with reasons, and where equal respect and consideration is paid to the multiple arguments that are presented ${ }^{54}$.

An objection to these arguments can be raised by stating that not only by writing positively about Congress will things become better. To this objection it should be replied, that knowing the limitations of the capabilities of courts in processes of democratization, and transformation of political institutions can help to construct realistic demands on the Courts role, and to acknowledge that the political branches are at least as crucial to the functioning of democracy as are the courts ${ }^{55}$. Also, in a theorethical level, the fact that a conception of democracy is hard to achive, does not entail that as a matter of principle it should be deemed as wrong ${ }^{56}$.

\section{CONCLUSIONS AND FINAL REMARKS}

As a modest conclusion, and even if it sounds as a truism, it should be stated that both the Brazilian and the Colombian Constitutions aimed at transforming their legislative institutions into pluralists, and deliberative forums, accountable to citizens,

\footnotetext{
52 GARGARELLA, Roberto. La Sala de Máquinas de la Constitución: dos siglos de constitucionalismo en América Latina (1810-2010). Katz Editores, 2015.

${ }^{53}$ Although some bargaining and compromise is inevitable in these legislative scenarios, there are devices of institutional design in order to put these situations in favor of weak political parties, such as by the establishment of super majorities in decisions that are highly valuable and sensitive.

${ }^{54}$ STEINER, Jurg. Citizens' Deliberation and Human Rights. In: SAUL, Mathew, Follesdal Andreas; ULFSTEIN, Geir (eds.). The International Human Rights Judiciary and National Parliments. Cambridge University Press, 2017.; STEINER, Jurg; JARAMILLO, Maria Clara; MAIA, Rousile; MAMELI, Simona. Deliberation Across Deep Divisions. Transformative Moments, Cambridge University Press, 2016.

55 GAVISON, Ruth. The Role of Courts in Drifted Democracies. Israel Law Review, vol. 33, n. 2, p. $216-258$. 1999.

56 ESTLUND, David. Epistemic Proceduralism and Democratic Authority. In: GEENES, Raf; TINNEVELT, Ronald (eds.). Does Truth Matter? Democracy and Public Space. Springer: Dordrecht, 2008.
} 
and capable of undertaking discussions of rights and principle. Even if the empirical situation does not favor this aspiration, there is an urgent need to rescue the legislatures and put them back in good shape, since they are institutions that can channel the voices of pluralist and diverse groups when deliberation is taken seriously. Also, it is hard to rescue the legislative branch from the ostracism if it is shown as a dispensable branch of government, a perception that can be easily exacerbated if most of the discussions on principle, rights and even public policy are made by the judiciary.

There is obviously a need to undertake legal reforms that strengthen political parties, aimed for example at the promotion of the participation of minority parties and social groups, and to guarantee the openness and honesty in political campaigns and congressional deliberation. Perhaps the role of the Brazilian and Colombian Courts in this transformation is better played by being the guardians of the rules of deliberation, by taking actions to promote pluralism, and by promoting the discussion among equals at the legislature, as a modest antidote to the dysfunctionality of such branch, than by making most of the decisions of principle, rights and public policy.

\section{REFERENCES}

ADLER, Matthew; DORF, Michael. C. Constitutional Existence Conditions and Judicial Review. Virginia Law Review, vol. 89, n. 6, 1105-1202, Oct. 2003.

BAUMAN, Richard; KAHANA, Tsvi. The least examined branch. Cambridge: Cambridge University Press, 2006.

BONILLA, Daniel (ed.). Constitucionalismo del Sur Global. Bogotá: Siglo del Hombre Editores. 2015.

BRADLEY THAYER, James. The Origin and Scope of the American Doctrine of Constitutional Law. Harvard Law Review, vol. 7, n. 3, Oct. 25, 1893.

CHRISTIANO, Thomas. The Authority of Democracy. The Journal of Political Philosophy, vol. 12, n. 3, 2004.

BRASIL. Constituição (1988). Constituição da República Federativa do Brasil. Brasília, DF: Senado Federal: Centro Gráfico, 1988.

DALY, Tom Gerald. The Alchemists: Questioning our Faith in Courts as Democracy-Builders. Cambridge: Cambridge University Press, 2017.

DORF, Michael C.; SABEL, Charles F. A Constitution of Democratic Experimentalism. Columbia Law Review, vol. 98, n. 2, Mar, 1998.

DWORKIN, Ronald. The forum of principle. New York University Law Journal, vol. 56, n. 469, 1981. ESTLUND, David (et. Al). The Place of Self-Interest and the Role of Power in Deliberative Democracy. The Journal of Political Philosophy, vol. 18, n. 1, 2010, p. 54-100. 
ESTLUND, David. Epistemic Proceduralism and Democratic Authority. In: GEENES, Raf; TINNEVELT, Ronald (eds.). Does Truth Matter? Democracy and Public Space. Springer: Dordrecht, 2008.

FALLON, Richard. The Core Of An Uneasy Case For Judicial Review. Harvard Law Review, vol. 121, n. 7, May, 2008.

GALLIE, W.B. Esentially Contested Concepts. Proceedings of the Aristotelian Society, vol. 56, n. 167, 1955-1956. p. 167-198.

GARGARELLA, Roberto. La Sala de Máquinas de la Constitución: dos siglos de constitucionalismo en América Latina (1810-2010). Buenos Aires: Katz Editores, 2015.

GARRET, Elizabeth; VERMEULE, Adrian. Institutional Design of a Thayeran Congress. Duke Law Journal, vol. 50, n. 5, 2001.

GAVISON, Ruth. Legislatures and the Phases and Components of Constitutionalism. In: BAUMAN, Richard; KAHANA, Tsvi (Eds.). The least examined branch. Cambridge: Cambridge University Press, 2006.

GAVISON, Ruth. The Role of Courts in Drifted Democracies. Israel Law Review, vol. 33, n. 2, p. 216-258. 1999.

HART ELY, John. Democracy and Distrust. Harvard University Press, 1980.

HAILBRONNER, Michaela. Transformative Constitutionalism: Not Only in the Global South, American Journal of Comparative Law, vol. 65, n. 3, p. 527-565. Nov. 13, 2017.

LANDAU, David. A Dynamic Theory of Judicial Role. Boston College Law Review, Boston, vol. 55, n. 5, p. 1501-1562. 2014.

LEMAITRE RIPOLL, Julieta. El Derecho Como Conjuro. Bogotá: Uniandes y Siglo del Hombre Editores, 2009.

MALISKA, Marcos. The Brazilian Judicial Review. Education \& Science Without Borders, Curitiba, vol. 6, n. 12, p. 54-57, 2015.

MANDEL, Michael, The Charter of Rights and the Legalization of Politics in Canada. Thompson Educational Publishers, 1994.

MANDEL, Michael. A Brief History of the New Constitutionalism, or "How We Changed Everything So that Everything Would Remain the Same. Israel Law Review. vol. 32, n. 2, 1998.

MARMOR, Andrei. Authority, Equality and Democracy. In: MARMOR, Andrei. Law in the Age of Pluralism. Oxford University Press, 2007.

MARMOR, Andrei. Constitutional Interpretation. USC Law and Public Policy Research Paper, Los Angeles, vol. 4, n. 4, 2004.

MARMOR, Andrei. Law in the Age of Pluralism. Oxford University Press, 2007. 
MARMOR, Andrei. Meaning and Belief in Constitutional Interpretation. Fordham Law Review, vol. 82, n. 565, Nov. 2013.

MARMOR, Andrei. Randomized Judicial Review. USC Law Legal Studies Paper, Los Angeles, vol. 15, n. 8, 2015.

MORTON, F.L.; KNOPFF, Rainer. The Charter Revolution \& The Court Party. University Toronto Press, 2000.

PARKER, Richard. “Here, the People Rule": A Constitutional Populist Manifesto. Boston: Harvard University Press, 1994.

RODRÍGUEZ GARAVITO, Cesar; RODRÍGUEZ FRANCO, Diana. Cortes y cambio social: cómo la Corte Constitucional transformó el desplazamiento forzado en Colombia. Colección Dejusticia, 2010.

ROSENBERG, Gerarld. The Hollow Hope. University of Chicago University Press, 2008.

ROSENN, Keith. Separation of Powers in Brazil. Duquesne Law Review, Miami, v. 47, p. 839-870, 2009.

STEINER, Jurg. Citizens' Deliberation and Human Rights. In: SAUL, Mathew, Follesdal Andreas; ULFSTEIN, Geir (eds.). The International Human Rights Judiciary and National Parliments. Cambridge University Press, 2017.

STEINER, Jurg; JARAMILLO, Maria Clara; MAIA, Rousile; MAMELI, Simona. Deliberation Across Deep Divisions. Transformative Moments, Cambridge University Press, 2016.

TUSHNET, Mark. Taking the Constitution Away from the Courts. Princeton University Press, 2000.

UNGER, Roberto Mangabeira. Democracy Realized: the progressive alternative. New York: Verso, 2001.

UPRIMNY YEPES, Rodrigo. Should Courts enforce Social Rights? The Experience of the Colombian Constitutional Court. In: COOMANS, Fons, (ed.). Justiciability of Economic and Social Rights: Experiences from Domestic Systems. Antwerpen-Oxford: Intersentia, 2006.

VIEIRA, Oscar Vilhena. The Descriptive Overview of the Brazilian Constitution and Supreme Court. In: VIEIRA, Oscar Vilhena (et. al.). Transformative Constitutionalism: comparing the apex courts of Brazil, India and South Africa, 2013.

WALDRON, Jeremy. Control de Constitutionalidad y Legitimidad Política. Díkaion, Vol. 27, No. 1, 2018.

WALDRON, Jeremy. Law and Disagreement. Oxford University Press, 1999.

WALDRON, Jeremy, The Dignity of Legislation. Cambridge University Press, 1999.

WALUCHOW, Wilfrid. A Common Law Theory of Judicial Review: The living Tree. Cambridge Studies in Philosophy and Law. 2009. 